\title{
Impact of Authoritarian Trends and Political Tribalism on Muslim Minorities in the US
}

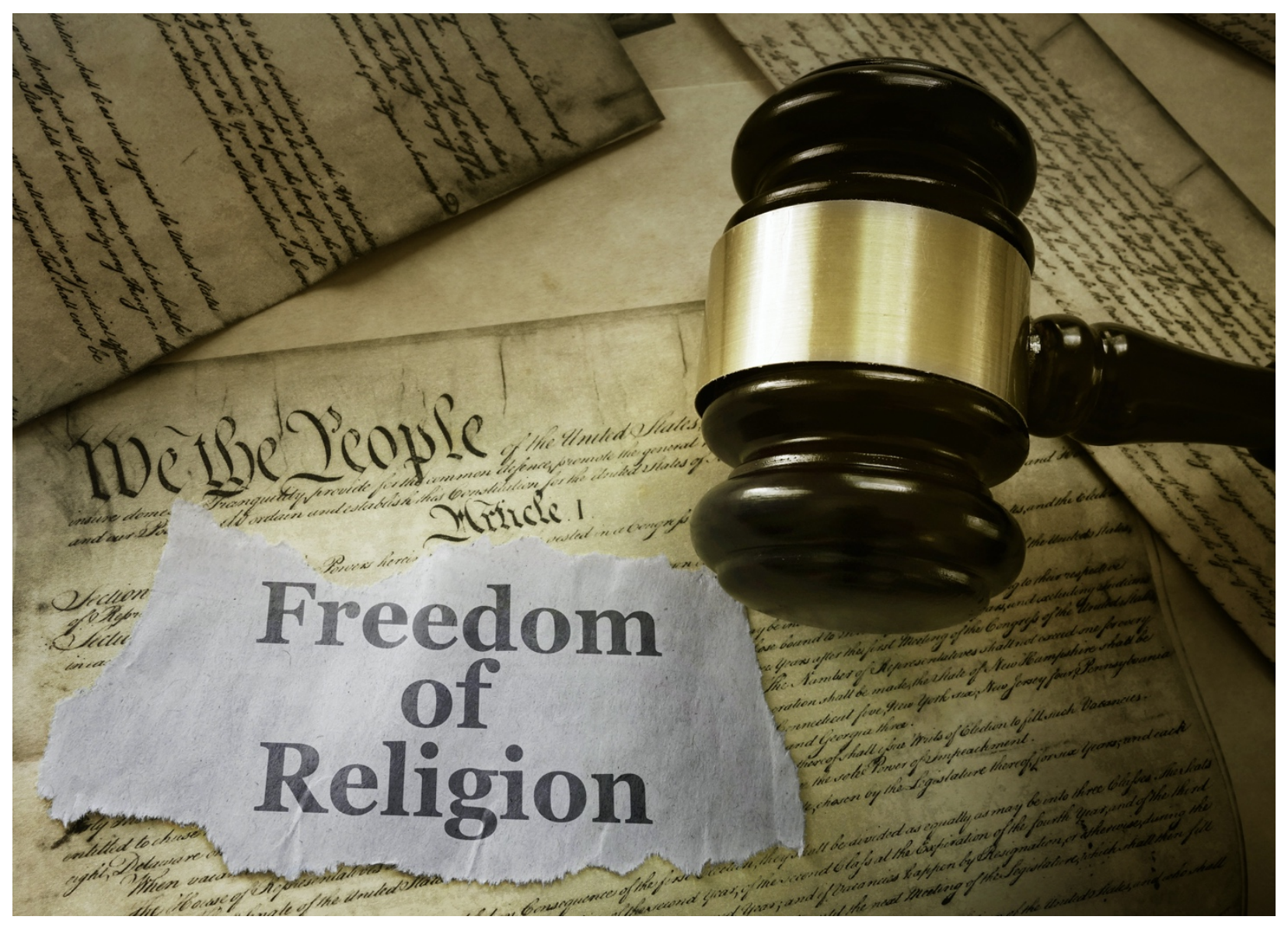

\section{Asma T. Uddin}

Inclusive America Project Fellow

Aspen Institute

Symposium on Authoritarianism and Good Governance

Muqtedar Khan (Ed.)

International Institute of Islamic Thought | February 2021

DOI: http://doi.org/10.47816/02.001.24 


\section{Introduction}

Donald Trump's presidency might be coming to a close, but the forces that elected him and continue to trumpet Trumpism are still very much influential. To counter Trump's appeal, we have to start by understanding it.

With that goal in mind, it helps to divide Trump's base into categories of concerns. This paper looks at the religious piece of the puzzle-the now infamous $81 \%$ of white evangelicals who helped elect him and were the focus of many of his policies and much of his pandering. This paper also examines the relationship between these evangelicals and Muslims as religious minorities. President Trump, after all, made Muslims one of the primary targets of his vitriol, and evangelicals reflected that same hostile attitude. While there are many drivers of this antagonism, this paper analyzes the impact of political tribalism-informed by group dynamics and social psychology-on how evangelicals perceive and react to Muslims.

\section{Group Identity and Intergroup Bias}

I once asked a roundtable of

people who work on religious engagement programs and religious freedom advocacy whether political tribalism drives anti-Muslim hostility among white evangelicals. One person responded, "Definitely. Everything is tribal nowadays. Muslims are part of a different religious tribe and inasmuch as they align with progressives, a different political tribe also." Another stated, "Yes. [Conservative white evangelicals] believe Democrats are trying to encourage Muslim immigration because it will help them de-Christianize America.”

To understand this dynamic, it is 
helpful to have a basic understanding of group identity. Much of what we know about group dynamics is based on a series of experiments conducted by social psychologist Henri Tajfel in the 1970s. In one study, he took sixty-four boys from the same school; the boys all knew each other and already had a sense of community among them. First, the researchers told the boys they wanted to test visual judgment. The boys were shown clusters of dots and had to estimate how many dots they saw. After the researchers tallied (or pretended to tally) the results, the researchers informed the boys that they were dividing them into groups: one included boys who had guessed a high number of dots on the visual judgment test and another consisted of those who had guessed low. In reality, the researchers divided the boys randomly; their purpose was only to test what happened next.
The researchers then gave the two groups some money and asked them to distribute it to other boys in the study. The boys couldn't keep any money for themselves; they had to give it to the others, but they chose how they would allocate the money and they knew if it went to members of their own group or the out-group. What Tajfel learned from the study shocked him about the power of group identity. Most of the boys in each group gave money to their own group members instead of to the outgroup. The boys had been divided on the basis of completely meaningless criteria, but they still chose their own group over the other one. There was no substantive benefit to choosing their own group, but they still did it because of the powerful pull of group identity.

In a second study, Tajfel changed the setup so that when the boys were allocating money, they had to choose between maximizing their own amount 
of money and maximizing how much more their group got compared to the out-group. The boys chose the latter. The boys were okay with giving their own group less so long as they had significantly more money than the outgroup.

As a series of subsequent experiments by Tajfel and others confirmed, people exhibit discriminatory intergroup behavior in a way that created the biggest gap between their group and the out-group: "Far from the money being the prime motivator, it is the winning that seems more important to them."

\section{Intergroup Bias and US}

\section{Partisanship}

Our allegiance to our political tribes is no different than the usual dynamic of group loyalty and intergroup bias. Elections are pure team rivalry. What is worse, however, is that in our present political climate, these group rivalries pose ever more serious implications because of what Lilliana Mason in Uncivil Agreement: How Politics Became Our Identity (2018) calls the emergence of "mega-identities": "A single vote can now indicate a person's partisan preference as well as his or her religion, race, ethnicity, gender, neighborhood, and favorite grocery store. This is no longer a single social identity. Partisanship can now be thought of as a mega-identity, with all the psychological and behavioral magnifications that implies."

It is the difference between sorting and polarizing. The first is issuebased polarization-we cluster together based on our policy opinions. The second is identity-based polarization-we cluster together based on political identities. "[O]ur political identities are polarizing our other identities, too," and issue 
conflicts are just one of many expressions of that hostility.

In this ever-widening circle, almost nothing is apolitical anymore. Consider a 2004 ad by the Club for Growth, a conservative group that advocates for lower taxes and deregulation, against then-presidential candidate Howard Dean. The ad features someone asking an older white couple what they think of Dean's plan, and the man responds: "II think Howard Dean should take his tax-hiking, governmentexpanding, latte-drinking, sushi-eating, Volvo-driving, New York Timesreading-.' His wife cuts in, 'Bodypiercing, Hollywood-loving, left-wing freak show back to Vermont, where it belongs." Each of these traits reinforces a particular mega-identity, and when you activate one, you activate them all.

Something like this appears to be at work when it comes to Muslims and liberals. Eboo Patel begins to get at this in Out of Many Faiths: Religious Diversity and the American Promise (2018), where he notes that Muslims are given platforms by outlets like The New York Times, NPR, CNN, The New Yorker-outlets that are

associated with urban, multicultural, progressive Whole Foods America; not so much white, rural, conservative Cracker Barrel America. One gets the sense that if Trump's America insists on casting Muslims as villains ... then Barack Obama's America will respond by promoting Muslims whom they consider heroes ... Muslims, in other words, have become a totem in the current chapter of the American culture wars, a symbol that signals, above all, a tribal belonging

(Trump/red/rural/evangelical/Cr 
acker Barrel versus Obama/blue/urban/secular/Who le Foods), with each tribe doing its best to foist on the category "Muslim" its preferred set of characteristics. $^{\mathrm{i}}$

In other words, Muslims-and especially liberal advocacy on behalf of Muslimsare traits of the liberal mega-identity and opposition to Muslims is a trait of the conservative mega-identity. What happens when American Muslims get lumped into a liberal mega-identity (that is, furthermore, defined by conservatives as anti-Christian and anti-America)? Muslims take on those traits, too.

The psychological implications are very dangerous, Mason says. When our racial, religious, and other identities are wrapped up with our political party, the impact on us psychologically is a lot worse if our party loses an election or some other partisan battle.i ${ }^{\text {ii }}$ It is akin to our losing the competition between racial and religious groups, too. It makes us feel threatened and we lash out against the out-group.

This is particularly the case now as many white Christian conservatives are feeling under siege. In-group favoritism does not always result in out-group bias but, in the religious context, tribalism has resulted in out-group hostility-and Muslims are one of the primary targets of this hostility.

\section{Perceptions of Threat: The End of White Christian America}

Perceptions of threat partly explain this phenomenon. Oxford political scientists Miles Hewstone, Mark Rubin, and Hazel Willis write, "The constraints normally in place, which limit intergroup bias to in-group favoritism, are lifted when out-groups are associated with stronger emotions." Stronger emotions include feelings like 
the out-group is moving against you: "an out-group seen as threatening may elicit fear and hostile actions." Whereas "high status" groups (those that are a numerical majority and have power) don't feel threatened by minorities when the status gap is very wide, they are more likely to feel vulnerable when the status gap is closing.

There are multiple demographic trends contributing to white evangelicals' perception of threat. For instance, and for the first time in US history, white racial dominance is on the decline. In 1965, white Americans constituted 84 percent of the US population. Since then, there has been an influx of immigrants, with nearly 59 million arriving in the last fifty years alone. Between 1965 and 2015, the American Asian population went from 1.3 million to 18 million, and the Hispanic population went from 8 million to almost 57 million. America's complexion is "browning" and in several states-including America's most populous ones, Texas and Californiawhites are already a minority. National Public Radio reported in 2016 that nonwhite babies now outnumber nonHispanic white babies.iii The majority of Americans under the age of 16 are nonwhite (and have been since the middle of 2020).iv Pew says whites generally will be a minority by $20555^{;}$the US Census says it will happen even sooner, in 2044. ${ }^{\mathrm{vi}}$

Second, and also for the first time in US history, white Protestant Christians are a minority in America. A 2017 PRRI study found that white Protestant Christians constitute only $43 \%$ of the US population. Robert Jones, the founder of PRRI, calls it the "end of White Christian America."vii To understand the gravity of the shift, consider that in 1976, eight in 10 Americans were white Christians, and $55 \%$ of Americans were white Protestants. In 1996, white Christians 
still made up two-thirds of the population. Today, they do not even constitute a majority. Among these white Protestants, white evangelicals have also seen a precipitous drop. In the 1990s, white evangelicals constituted $27 \%$ of the US population; today it is somewhere between $17 \%$ and $13 \%$.viii

Third, the demise of white Protestant America has brought with it an end to "the cultural and institutional world built primarily by white Protestants that dominated American culture until the last decade." Not only is Christianity declining, but so is religion overall. More and more Americans are religiously unaffiliated (the so-called "nones"), and in 2019 the percentage of nones became roughly the same as the percentage of evangelicals or Catholics. ${ }^{\text {ix }}$ (By 2016, the nones already constituted the nation's largest religious voting bloc.) ${ }^{x}$ The massive shift signaled growing discontent with organized religion generally. Altogether, Jones says, this has precipitated an "internal identity crisis" that has generated tremendous anger, insecurity, and anxiety. Unfortunately, that anger has been directed outwards toward a number of minority groups-Muslims included.

\section{Impact on Religious Minorities:}

\section{Dismissiveness about Anti-Muslim}

\section{Discrimination}

There are several theories regarding why threat leads to bias. One is Tajfel's social identity theory. When a high-status group protects its members, the members feel greater self-esteem. When that status is challenged, members feel depressed and lash out at the threatening out-group. There are studies on two closely-related socialpsychological traits that posit something similar.

Social Dominance Orientation 
The first trait is social dominance orientation (SDO), or a desire to want one's group to dominate the out-group. Feelings of vulnerability make this tendency worse. Scholars have tested the connection between SDO and support for Trump. Professors Rogers M. Smith and Desmond King write that a "wide variety of studies, including experimental research, public opinion surveys, analyses of voting statistics, and panel studies show that [Trump's] victim narrative connected powerfully with those with strong attachments to traditionally dominant identities."xi Political scientist Diana C. Mutz found these trends even among people who in past elections might not have voted for Trump. People who felt their status was threatened experienced an increase in SDO-that is, a desire to dominate the out-group-which in turn led them to "defect to Trump."xii
Mutz tested this specifically with respect to attitudes toward Muslims. Respondents were asked to what extent Muslims and Christians (among others) were discriminated against in America. She found that people who voted for Trump perceived Christians as experiencing greater discrimination than Muslims. Other studies, while not connecting it to SDO specifically, have also documented the partisan divide when it comes to attitudes about antiMuslim discrimination. In 2020, the University of Chicago Divinity School and the Associated Press-NORC Center for Public Affairs Research (AP-NORC) found that while half of Americans believe that American Muslims' religious freedom is threatened at least somewhat, only about 3 in 10 white evangelicals said the same. xiii In 2019, Pew found that Democrats and those who lean Democratic "are more likely than Republicans and Republican leaners to 
say Muslims face at least some discrimination in the U.S. (92\% vs. $69 \%$ ) ... At the same time, Republicans are much more likely than Democrats to say evangelicals face discrimination (70\% vs. 32\%)."xiv

In 2017, the Rasmussen Report found that "[f]ifty-six percent $(56 \%)$ of Democrats ... believe most Muslims in this country are mistreated, a view shared by only $22 \%$ of Republicans." ${ }^{\mathrm{xv}}$ That same year, PRRI found that Democrats were four times as likely to believe that Muslims faced greater discrimination than Christians. Republicans thought the two groups suffered roughly equally, but among white evangelicals specifically, PRRI found that 57 percent said that antiChristian discrimination is widespread in the US while only 44 percent said the same thing about anti-Muslim discrimination. ${ }^{\mathrm{xvi}}$
Similar to Mutz's findings, there appeared to be a correlation between the political climate and perceptions of status threat. Polls from several years or even a year before the 2016 presidential election found that fewer white evangelicals thought they faced more discrimination than Muslims. A 2013 PRRI survey found that 59 percent of white evangelicals thought Muslims faced more discrimination than evangelicals did; 56 percent responded that way to an October 2016 poll. By February 2017, that number had dropped 12 percentage points. ${ }^{x v i}$

\section{Authoritarianism}

Scholars have separately studied a second social-psychological trait called "authoritarianism," which refers to a personality type that sees the world as black-and-white and society as fragile, seeking to impose hierarchy, order, and 
uniformity. In a study published in 2011, Marc Hetherington and Elizabeth Suhay tested the connection between authoritarianism and perceptions of threat from terrorism and found that people who score high on authoritarianism do not "become more hawkish or less supportive of civil liberties in response to a perceived threat of terrorism"; they hold these positions even in the absence of threat. However, people "who are less authoritarian adopt more restrictive and aggressive policy stands when they perceive a threat from terrorism. In other words, many average Americans become susceptible to 'authoritarian thinking' when they perceive a grave threat to their safety." xviii

A similar tendency comes into play when Christians feel threatened about their status in the US-they begin to acquiesce to the views of Christian nationalists (those who seek to define America as a Christian nation and exclude minorities like Muslims from the national fabric). Political scientist Andrew Lewis explained it to me this way: "Those who are constantly inundated with perspectives that Christianity is threatened (even if they are not necessarily hostile to other religious faiths) are more likely to accommodate Christian nationalist views on their own side. Trying to push back against nationalism from your team and religious discrimination on the other team is a difficult path to follow."xix That is, it is difficult for many non-nationalists to both resist liberals' attacks on their Christian practices and also resist Christian nationalists' push to privilege Christianity. So, they accommodate the rhetoric and tactics of the Christian nationalists, even if they are more open to diverse faiths.

Importantly, Lewis says, "All of this is wrapped up in partisanship, as partisan leaders prime these responses- 
both out-group intolerance and in-group protection. In some eras, partisans have played homage to protecting Christians from losing ground to secularism or liberals. But now partisans on the Right are increasingly emphasizing both secularism and liberalism, as well as Islam and other foreign religions.” This explains Mutz's findings, too-Trump's deft use of the victim narrative helped attract voters who were experiencing status threat. On the campaign trail, he told them in the clearest terms, "We will have so much winning if I get elected, that you may get bored with winning." In a nutshell, then, authoritarianism and SDO are triggered by a perceived threat and people respond by protecting the ingroup and excluding the threatening outsider. Lewis calls it "activated vulnerability."

\section{Impact on Religious Minorities: \\ Opposition to Muslims' Rights}

The conflation of the threatening Left with Muslims extends beyond just rhetorical posturing. The political divides are exacerbated regularly by professional fearmongers who develop far-fetched conspiracy theories and the influential figures in media and politics who disseminate the theories. Altogether, these efforts result in significant legal challenges to Muslims' religious rights, from building mosques to anti-bullying programs in public schools.

Many of the conspiracy theories originate at the Center for Security Policy (CSP). CSP-funded author Jim Simpson authored two books on the subject: The Red-Green Axis: Refugees, Immigration and the Agenda to Erase America (2015) and The Red-Green Axis 2.o: An Existential Threat to America and the World (2019). The "Red" points to the red in the communist hammer and sickle emblem, and implicitly connects the political Left, communism, and 
socialism. The "Green" points to the green often found in the national flags of majority-Muslim countries; green symbolizes Islam. According to Simpson, this axis of Islam and liberalism endeavors to re-create America and fundamentally alter its culture-a process he calls "civilization jihad."

CSP-funded writer Matthew Vadum discusses a similar theme in Team Jihad: How Sharia-Supremacists Collaborate with Leftists to Destroy the United States (2017). Meanwhile, David Horowitz, well-known for his antiMuslim advocacy, wrote Unholy Alliance: Radical Islam and the American Left back in 2006. In addition, Andrew McCarthy, a former Assistant US attorney and a columnist for the National Review, proposes a similar theory in The Grand Jihad: How Islam and the Left Sabotage America (2010).

In all cases, the idea is that the political Left in the US is working with
Muslims to destroy America's Christian character. The fearmongers reason from this that any attempt by liberals to expand protections or rights for Muslims must be resisted as part of a broader effort to preserve the US as a Christian nation. Among other things, this impulse has resulted in a nationwide resistance movement to mosque-building. Guided by CSP's handbook, "Mosques in America: A Guide to Accountable Permit Hearings and Continuing Citizen Oversight," ${ }^{x x i}$ Americans have learned to "express questions and reservations in a manner appropriate to the relevant civic forum's purpose" and avoid "expressing alarm as hysteria" as that could be "used to characterize the entire oversight effort as racially biased and ignorant." The efforts have borne many successes; today, mosque construction is almost always challenged and often delayed by years due to these protests. 
In the public school context, Christian advocacy groups like the Freedom of Conscience Defense Fund (FCDF) and American Center for Law and Justice (ACLJ) regularly challenge accommodations for Muslim students in public schools. FCDF has successfully contested a Washington state school district that sought to provide a welcoming environment for Muslim students fasting during Ramadan. FCDF is also currently planning to oppose an anti-bullying program in Minneapolis which was created in response to complaints about faith-based bullying filed by the city's large Somali-Muslim population. ${ }^{x x i i}$ Furthermore, it is investigating a program in Seattle public schools that seeks to better inform students about Islam and its holidays as well as create a safer and more accepting atmosphere for Muslim students. ${ }^{\text {xiii }}$

Meanwhile, with ACLJ's help, parents and students have protested against school lessons on Islam, which is taught in cultural and historical terms alongside other religions in various social studies courses. In a Georgia case, parents balked at a worksheet that tested students on various Muslim beliefs. They objected in particular to the fill-in-theblank sentence: "Allah is the [blank] worshipped by Jews \& Christians," the correct answer being "same God."xxiv In Maryland, a student challenged another fill-in-the-blank sentence about the Islamic creed. Students had to answer that, according to Islam, "There is no god but Allah and Muhammad is the messenger of Allah." After the complaining student lost her case in the appellate court, she took it to the US Supreme Court, which turned it down in October 2019. ${ }^{x x v}$ In New Jersey, the same fill-in-the-blank sentence, given as homework after students watched a brief cartoon video on the five pillars of Islam, ignited complaints that landed the 
parents on Fox's "Tucker Carlson Tonight.” The discussion there alleged that the school district "was suppressing discussion about Christianity while proselytizing Islam." ${ }^{x x v i}$ In other cases, oppositions like this have resulted in everything from textbooks being rewritten to schools being placed in emergency lockdowns due to threats.

\section{Conclusion}

America is increasingly becoming consumed with political tribalism. Our political identities have morphed well beyond issue positions to include racial, religious, and other traits, such that an electoral loss for our team exerts tremendous psychological pressure on us. This polarization, coupled with perceptions of threat that heighten social-psychological tendencies toward social dominance and authoritarianism, results in concrete harm to religious (and other) minorities. That is, tribalism sets up the dynamic that transforms members of the out-group from fellow humans who are entitled to human rights to members of an out-group who must be defeated at all cost, lest our own team "loses."

This phenomenon is evident in the treatment of Muslims' rights in the US. Not only is anti-Muslim discrimination minimized by this focus on Christians' own sense of victimhood, it also manifests in active social, political, and legal challenges to Muslims' religious rights. 


\section{Author Bio}

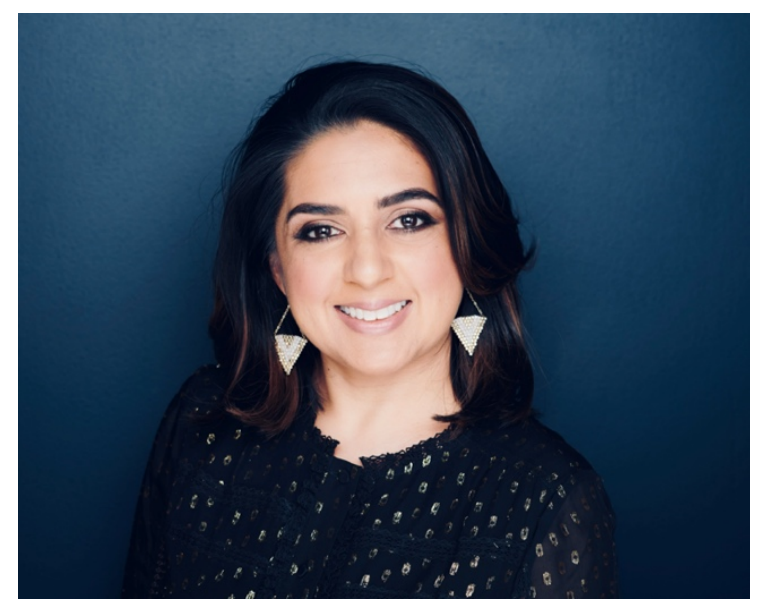

Asma Uddin is the author of When

Islam Is Not a Religion: Inside

$\underline{\text { America's Fight for Religious }}$

Freedom and the forthcoming The

Politics of Vulnerability: How to Heal

Muslim-Christian Relations in a Post-

i Patel, Eboo. 2018. Out of Many

Faiths: Religious Diversity and the

American Promise. Princeton:

Princeton University Press.

ii YouTube. 2018. "Lilliana Mason on

Uncivil Agreement." Last modified

May 1, 2020.
Christian America. She is an Inclusive America Project Fellow at the Aspen Institute, where she is leading a project on Muslim-Christian polarization in the U.S. Ms. Uddin was formerly legal counsel at the Becket Fund for Religious Liberty, and has held academic fellowships at Georgetown, UCLA, and Brigham Young University Law School. She is also an expert advisor on religious freedom to the Organization for Security and Cooperation in Europe, and a termmember of the Council on Foreign Relations.

\section{End Notes}

https://www.youtube.com/watch?v=TC 4SQ9oasnU iii Yoshinaga, Kendra. "Babies of Color Are Now the Majority, Census Says." National Public Radio, July 1, 2016. https://www.npr.org/sections/ed/2016/0 7/01/484325664/babies-of-color-arenow-the-majority-census-says 
iv Schneider, Mike. 2020. "Census shows white decline, nonwhite majority among youngest." Associated Press, June 25, 2020.

https://apnews.com/a3600edf620ccf275 9080d00f154c069

v Pew Research Center. 2015. "Modern Immigration Wave Brings 59 Million to U.S., Driving Population Growth and Change Through 2065." Last modified September 28, 2015. https://www.pewresearch.org/hispanic/ 2015/09/28/modern-immigration-wavebrings-59-million-to-u-s-drivingpopulation-growth-and-changethrough-2065/\#post-1965immigration-drives-u-s-populationgrowth-through-2065

vi US Census. 2014. "Projecting Majority-Minority." https://www.census.gov/content/dam/C ensus/newsroom/releases/2015/cb15tps16_graphic.pdf vii Jones, Robert P. 2016. End of White Christian America. New York: Simon \& Schuster.

viii Sherwood, Harriet. 2018. "'Toxic Christianity': the evangelicals creating champions for Trump." Guardian, October 21, 2018. https://www.theguardian.com/usnews/2018/oct/21/evangelicalchristians-trump-liberty-universityjerry-falwell ix Smith, Samuel. 2019. "Religious 'nones' now as big as evangelicals in the US, new data shows." Christian Post, March 20, 2019.

https://www.christianpost.com/news/re ligious-nones-now-as-big-asevangelicals-in-the-us-new-datashows.html x Ingraham, Christopher. 2016. "The non-religious are now the country's largest religious voting bloc." Washington Post, July 14, 2016. https://www.washingtonpost.com/news /wonk/wp/2016/07/14/the-nonreligious-are-now-the-countryslargest-religious-voting-bloc/ xi Smith, Rogers M. and Desmond King. "White Protectionism in America." doi:10.1017/S1537592720001152 xii Mutz, Diana C. "Status threat, not economic hardship, explains the 2016 presidential vote." Proceedings of the National Academy of Sciences May 2018, 115 (19) E4330-

E4339; DOI:10.1073/pnas.1718155115 
xiii Schor, Elana and Hannah

Fingerhut. 2020. "Religious Freedom in America: Popular and Polarizing." The Telegraph, August 5, 2020. xiv Masci, David. 2019. "Many Americans see religious discrimination in U.S.—especially against Muslims.” Pew Research Center, May 17, 2019. https://www.pewresearch.org/fact$\operatorname{tank} / 2019 / 05 / 17 /$ many-americans-seereligious-discrimination-in-u-sespecially-against-muslims/ xv Rasmussen Reports. 2017.

"Democrats Think Muslims Worse Off Here Than Christians Are in Muslim World." Last modified February 7, 2017.

https://www.rasmussenreports.com/pu blic_content/politics/general_politics/fe bruary_2017/democrats_think_muslim s_worse_off_here_than_christians_are _in_muslim_world xvi Cox, Daniel and Jones, Robert P. 2017. "Majority of Americans Oppose Transgender Bathroom Restrictions." PRRI, March 10, 2017. https://www.prri.org/research/lgbttransgender-bathroom-discriminationreligious-liberty/ xvii Green, Emma. 2017. "White Evangelicals Believe They Face More Discrimination Than Muslims." The Atlantic, March 10, 2017. https://www.theatlantic.com/politics/ar chive/2017/03/perceptionsdiscrimination-muslimschristians/519135/ xviii Hetherington, Marc J., and Elizabeth Suhay. "Authoritarianism, Threat, and Americans' Support for the War on Terror." American Journal of Political Science 55, no. 3 (2011): 546-60. Accessed June 22, 2020. www.jstor.org/stable/23024936. (emphasis mine) xix Interview on file with author. xx Kaufman, Scott Eric. 2015. "Donald Trump: If elected, 'we'll have so much winning, you'll get bored with winning." Salon, September 9, 2015. https://www.salon.com/2015/09/09/don ald_trump_if_elected_well_have_so_m uch_winning_youll_get_bored_with_wi nning/ xxi Lugo, Karen. 2016. Mosques in America: A Guide to Accountable Permit Hearings and Continuing Citizen Oversight. Washington, DC: Center for Security Policy Press. 
http://www.centerforsecuritypolicy.org/ wp-

content/uploads/2016/12/Mosque_in_A merica.pdf xxii FCDF. 2018. "FCDF Demands Emails from Minneapolis Public Schools Regarding Relationship with CAIR.” August 17, 2018. https://www.fcdflegal.org/fcdfdemands-emails-from-minneapolispublic-schools-regarding-relationshipwith-cair/ xxiii FCDF. 2018. "FCDF Sends Letter to Seattle Public Schools Regarding Pro-Muslim Program.” July 8, 2018. https://www.fcdflegal.org/fcdf-sendsletter-to-seattle-public-schoolsregarding-pro-muslim-program/ xxiv Tagami, Ty. 2015. "Lessons about religion stir, and are stirred by, suspicion of Islam." The Atlanta

Journal-Constitution, October 5, 2015.

https://www.ajc.com/news/localeducation/lessons-about-religion-stirand-are-stirred-suspicionislam/w6nfM7CMxchh1fOantyGZO/ xxv Bloomberg Law. 2019. "Islam in Public School Challenge Rejected by Supreme Court.” October 15, 2019. https://news.bloomberglaw.com/uslaw-week/islam-in-public-schoolchallenge-rejected-by-supreme-court xxvi Katz, Matt. 2017. "Allegations of Islam Indoctrination in Public Schools Spread to New Jersey." WNYC, April $10,2017$.

https://www.wnyc.org/story/allegations -islam-indoctrination-public-schoolsspread-nj/ 